production of $95.6 \mu \mathrm{g} / \mathrm{ml})^{23}$, Lyptolingbya sp. (maximum production of $51.06 \mu \mathrm{g} / \mathrm{ml})^{8}$, Gietlerinema sp. (maximum production of $67.87 \mu \mathrm{g} / \mathrm{ml})^{8}$, Oscillatoria sp. TCC4 (maximum production of $10.65 \mu \mathrm{g} / \mathrm{ml})^{24}$ and Arthrospira platensis strain MMG-9 (maximum production of $113 \mu \mathrm{g} / \mathrm{ml})^{6}$. The production of IAA by $F$. muscicola is highest (maximum production of $286.82 \mu \mathrm{g} / \mathrm{ml}$ ) among the bacteria and cyanobacteria reported so far. Hence, the extract of this strain promotes growth of rice seedlings several times in comparison to control. This cyanobacterium can be a good biofertilizer and the extract can be used instead of synthetic agents for organogenesis induction in tissue culture.

1. Waterbury, J., The cyanobacteria isolation, purification and identification of the prokaryotes. In The Prokaryotes (eds Dworkin, M. et al.), Springer, New York, USA, 2006, vol. 4, pp. 1053-1073.

2. Garcia-Pichel, F., Belnap, J., Neuer, S. and Schanz, F., Estimates of global cyanobacterial biomass and its distribution. Algol. Stud., 2003, 109, 213-228.

3. Burja, A. M., Banaigsm, B., Abou-Mansour, E., Burgess, J. G. and Wright, P. C., Marine cyanobacteria - a prolific source of natural products. Tetrahedron, 2001, 57, 9347-9377.

4. Williams, P. G., Yoshida, W. Y., Moore, R. E. and Paul, V. J., Micromide and guamamide: cytotoxic alkaloids from a species of the marine cyanobacterium Symploca. J. Nat. Prod., 2004, 67, 49-53.

5. Christiansen-Weniger, C., Endophytic establishment of diazotrophic bacteria in auxin-induced tumors of cereal crops. Crit. Rev. Plant Sci., 1998, 17, 55-76.

6. Mehboob, A., Stal, L. J. and Hasnain, S., Production of indole-3acetic acid by the cyanobacterium Arthrospira platensis strain MMG-9. J. Microbiol. Biotechnol., 2010, 20(9), 1259-1265.

7. Prasanna, R., Joshi, M., Rana, A. and Naina, L., Modulation of IAA production in cyanobacteria by tryptophan and light. Pol. J. Microbiol., 2010, 59(2), 99-105.

8. Venkatesh Babu, S., Ashok Kumar, B., Sivakumar, N., Sudhakamamy, P. and Varalakshmi, P., Indole-3-acetic acid from filamentous cyanobacteria: screening, strain identification and production. J. Sci. Indust. Res., 2013, 72, 581-584.

9. Manickavelu, A., Nadarajan, N., Ganesh, S. K., Ramalingam, R., Raguraman, S. and Gnanamalar, R. P., Organogenesis induction in rice callus by cyanobacterial extracellular product. Afr. J. Biotechnol., 2006, 5(5), 437-439.

10. Costacurta, A. and Vanderleyden, J., Synthesis of phytohormones by plant associated bacteria. Crit. Rev. Microbiol., 1995, 21(1), 1-18.

11. Singh, J., Mishra, S. K. and Dwivedi, N., Antibacterial activity of two cyanobacteria Nostoc polludosum and Cylindrospermum licheniforme. J. Algal Biomass Util., 2017, 8(4), 18-22.

12. Stanier, R. Y., Kunisawa, R., Mandel, M. and Cohen-Bazire, G., Purification and properties of unicellular blue-green algae (order Chroococcales). Bacteriol. Rev., 1971, 35, 171-205.

13. Castenholz, R. W., General characteristics of the cyanobacteria. In Bergey's Manual of Systematic Bacteriology (eds Boon, D. R. and Castenholz, R. W.), Springer, New York, USA, 2001, vol. 1, 2nd edn, pp. 474-487.

14. Desikachary, T. V., Cyanophyta. Indian Council of Agriculture Research, New Delhi, 1959, p. 601.

15. Rippka, R., Deruelles, J., Waterbury, J. B., Herdman, M. and Stanier, R. Y., Generic assignments, strain histories and properties of pure culture of cyanobacteria. J. Gen. Microbiol., 1979, 111, 1-61.

16. Komárek, J., Cyanoprokaryota 3. Heterocytous genera. In Süßwasserflora Von Mitteleuropa/Freshwater Flora of Central Europe (eds Gärtner, G., Krienitz, L. and Schagerl, M.), Springer, Heidelberg, Germany, 2013, p. 1130.
17. Singh, S. P., Rastogi, R. P., Häder, Donat-P. and Sinha, R. P., An improved method for genomic DNA extraction from cyanobacteria. World J. Microbiol. Biotechnol., 2011, 27, 1225-1230.

18. Glickmann, E. and Dessaux, Y., A critical examination of the specificity of the Salkowski reagent for indolic compounds produced by phytopathogenic bacteria. Appl. Environ. Microbiol., 1995, 61, 793-796.

19. Pillay, D. T. N. and Mehdi, R., Separation of simple indole derivatives by thin layer chromatography. J. Chromatogr., 1968, 32, 592.

20. Ahmad, F., Ahmad, I. and Khan, M. S., Indole acetic acid production by the indigenous isolates of Azotobacter and fluorescent Pseudomonas in the presence and absence of tryptophan. Turk. J. Biol., 2005, 29, 29-30.

21. Sridevi, M. and Mallalah, K. V., Production of indole-3-acetic acid by Rhizobium isolates from Sesbania species. Afr. J. Microbiol. Res., 2007, 1, 125-128.

22. Spaepen, S., Vanderleyden, J. and Remans, R., Indole-3-acetic acid in microbial and microorganism-plant signaling. FEMS Microbiol., 2007, 31(4), 425-428.

23. Ahmad, N. and Fatma, T., Production of IAA by cyanobacterial strains. Nat. Prod. J., 2017, 7(2), 112-120.

24. Bhosale, A., Puranik, P. and Pawar, S., Screening and optimization of indole-3-acetic acid producing non-heterocystous cyanobacteria isolated from saline soil. Sch. Acad. J. Biosci., 2016, 4(9), 738-744.

ACKNOWLEDGEMENTS. We thank Dr Major Singh (Indian Institute of Vegetable Research, Varanasi) for sequencing the partial 16rRNA gene of the strain under study. A.R.P. thanks the Department of Science and Technology, New Delhi for providing a scholarship under the INSPIRE scheme.

Received 10 July 2016; revised accepted 21 October 2018

doi: $10.18520 / \mathrm{cs} / \mathrm{v} 116 / \mathrm{i} 7 / 1233-1237$

\section{Pedotransfer functions for predicting soil hydraulic properties in semi-arid regions of Karnataka Plateau, India}

\author{
S. Dharumarajan ${ }^{1, *}$, Rajendra Hegde ${ }^{1}$, \\ M. Lalitha ${ }^{1}$, B. Kalaiselvi ${ }^{1}$ and S. K. Singh ${ }^{2}$ \\ ${ }^{1}$ ICAR-National Bureau of Soil Survey and Land Use Planning, \\ Regional Centre, Hebbal, Bengaluru 560 024, India \\ ${ }^{2}$ ICAR-National Bureau of Soil Survey and Land Use Planning, \\ Amaravati Road, Nagpur 440 033, India
}

Soil hydraulic properties are important for irrigation scheduling and proper land-use planning. Field capacity, permanent wilting point and infiltration rate are the three vital hydraulic properties which determine the availability and retention of water for crop growth. These properties are difficult to measure and time-consuming, but can be easily predicted from the available information like soil texture, bulk density,

*For correspondence. (e-mail: sdharmag@gmail.com) 
organic carbon content, etc. through pedotransfer functions (PTFs). PTFs were developed for field capacity and permanent wilting point for two different regions of Karnataka, viz. Northern Karnataka Plateau (512 soil samples) and Southern Karnataka Plateau (228 soil samples), separately. PTF for infiltration rate was developed using 100 soil samples for the entire Karnataka. Cross-validation techniques were used to validate the PTFs, and the results are satisfactory with low RMSE and higher $R^{2}$. The developed PTFs are useful in determining soil hydraulic properties of the semi-arid regions of southern India.

Keywords: Pedotransfer functions, field capacity, permanent wilting point, infiltration rate, semi-arid regions.

GROWTH of plants mainly depends on available water content of the soil. The quality and quantity of water available for plant growth is determined by the soil hydraulic properties. When the water content reduces beyond 15 bar $(1500 \mathrm{kPa})$, most of the crops starts wilting. Hence, information about the soil water regime is important for judicial planning of irrigation ${ }^{1}$. Soil moisture constants, viz. field capacity, wilting point and infiltration rate are the most important soil hydraulic properties which decide the application and frequency of irrigation. Field capacity refers to the soil water content retained in soil micropores and macropores at a tension of $-0.033 \mathrm{MPa}$, whereas permanent wilting point is the soil water content at a tension of $-1.5 \mathrm{MPa}$. The difference in field capacity and permanent wilting point is the water available to the plants. Infiltration is defined as the process by which a fluid passes through or into another substance travelling through pores and interstices ${ }^{2}$, which widely influences irrigation, contaminant transport, groundwater recharge, and ecosystem viability ${ }^{3}$. Determination of these soil hydraulic properties is much important as it decides the soil moisture availability and suitability for crop production.

In large areas measuring the field capacity, wilting point and infiltration rate even within an agricultural field is time-consuming and expensive ${ }^{4}$, and it is also impossible to take enough measurements as these properties vary at each sampling point. Several methods have been proposed to estimate soil hydraulic properties from easily measured soil properties, e.g. texture and bulk density (BD), and/or limited data collected during soil surveys ${ }^{5-7}$. An equation or model developed for indirect estimation of a particular soil property is termed as pedotransfer function $(\mathrm{PTF})^{8}$. PTFs are an alternative method for estimation of hydraulic properties using available soil parameters, since field measurement of soil hydraulic properties consumes time, is tedious and costly. Practically most of the PTFs use the particle size distribution data of the soil, or its derived parameters, and other easily measurable soil properties, e.g. soil texture, BD, calcium carbonate content, $\mathrm{pH}$ value, etc. ${ }^{9,10}$. PTFs add value to this basic information by translating it into estimates of other more laborious and expensively determined soil properties $^{11}$.

Several PTFs were developed in India to estimate the soil hydraulic properties ${ }^{7,12-14}$. PTFs developed for a particular agroecological regions may not be useful for other region. Cornelis et al. ${ }^{15}$ showed that a PTF yields more accurate estimates when it is applied to the geographical region for which it was developed. In India, interrelationships between soil texture, water retention and transmission characteristics have been worked out in the past $^{7,13,16,17}$. PTFs were developed for the Indo-Gangetic Plains (IGP) ${ }^{7,18}$, black soil region $(\mathrm{BSR})^{18}$ and arid western India ${ }^{1}$. PTFs developed for a particular region have limited applicability in another region ${ }^{12}$. For southern India Deccan Plateau (semi-arid region), no comprehensive PTFs are available. In this context, the present study was aimed to develop PTFs for field capacity, permanent wilting point and infiltration of Karnataka Plateau representing semi-arid regions of southern India.

The present study was carried out in two different regions of Karnataka Plateau, viz. Northern Karnataka Plateau (NKP) and Southern Karnataka Plateau (SKP). The study area extends from $11^{\circ} 30^{\prime} \mathrm{N}$ to $18^{\circ} 30^{\prime} \mathrm{N}$ and $74^{\circ} \mathrm{E}$ and $78^{\circ} 30^{\prime} \mathrm{E}$ (Figure 1). Northern Karnataka Plateau (Koppal, Raichur, Yadgir and Gulburga districts): This region experiences hot, semi-arid climate with rainfall in the range $600-750 \mathrm{~mm}$ and potential evapotranspiration (PET) of 1600-1700 $\mathrm{mm}$. The average annual rainfall is $672 \mathrm{~mm}$. The length of growing period (LGP) ranges between 90 and 120 days. The major area comes under rainfed cultivation with rainfed crops like sorghum, pigeon pea and pearl millet. Northern Karnataka falls under Krishna and Godavari basins, and has topography of $300-600 \mathrm{~m}$ with sporadic hills. Substantial area is underlined by basalts with continuation of Deccan Trap of Maharashtra. The major soils are shallow to deep black soils, red loam soils, red clay soils, alluvio-colluvial soils and laterite gravelly soil ${ }^{19}$.

Southern Karnataka Plateau (Tumkur and Chamarajanagar districts): This region comes under hot semi-arid climate, with rainfall in the range $600-900 \mathrm{~mm}$ and mean annual rainfall of $735 \mathrm{~mm}$. The LGP ranges between 120 and 150 days. The major crops under rainfed cultivation are finger millet, pigeon pea and groundnut. Under irrigated condition, the major land use is paddy and sugarcane. Southern Karnataka falls under the Cauvery basin and has topography of 600-900 m with residual hills. Most of the area is underlined by granite and granite gneiss. The major soils are red gravelly loamy soils, red loam soils, red gravelly clay soils, red clay soils, laterite soils and aluvio-colluvial soils.

Soil physical properties such as sand, silt, clay, organic carbon (OC), pH, electrical conductivity (EC), cation exchange capacity (CEC) and exchangeable sodium percentage (ESP), field capacity (FC) and permanent wilting point (PWP) for major soil groups in study region under 


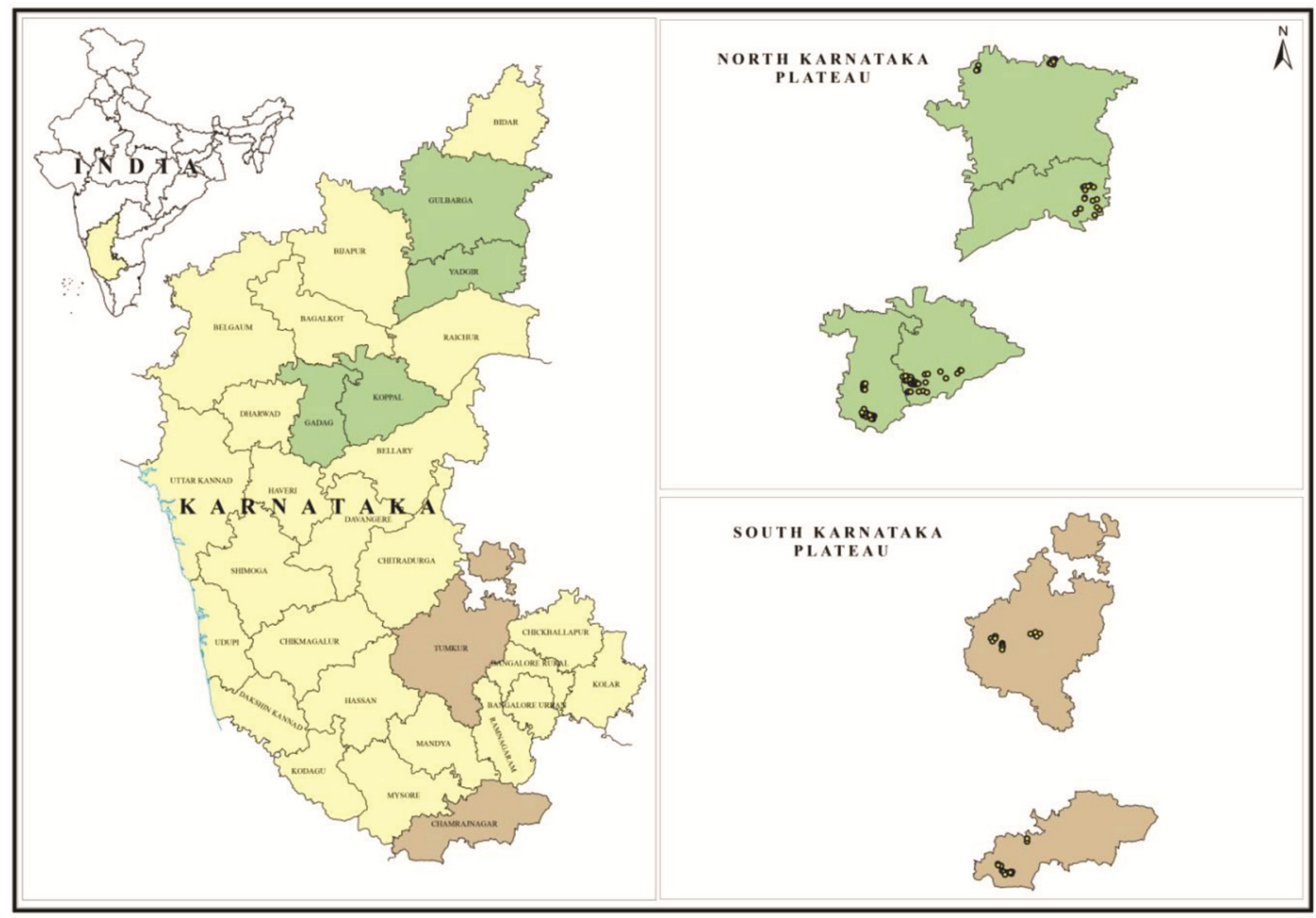

Figure 1. Study area.

Sujala III project ${ }^{20}$ (http://watershed.kar.nic.in/SujalaIII Doc.htm) were used for developing PTFs. A total of 512 soil samples (106 profiles) in NKP and 228 samples (43 soil profiles) in SKP were collected and analysed at ICAR-National Bureau of Soil Survey and Land Use Planning (NBSS\&LUP), Bengaluru according to standard protocol. Infiltration rate was measured at field using double-ring infiltrometer ${ }^{21}$ by the University partners under Sujala III project.

The random forest 4.6 package in $\mathrm{R}$ environment was used to identify the most important variables or predictors $^{22}$. Random forest model (RFM) works based on assemblage of a number of classification and regression trees using two levels of randomization for every tree in the forest ${ }^{23}$. RFM also identifies the relatively important variables based on the number of times a variable was used in the nodes ${ }^{24,25}$. Three topmost important variables were utilized for PTF development using multiple regression technique.

Multiple regression technique was used for developing PTFs in R environment (RStudio10.0). The PTFs for FC and PWP were developed separately for soils of NKP and SKP, since soils and climate of these regions are significantly different. The results were validated using crossvalidation techniques. The top-most important variables selected were used for estimating $\mathrm{FC}$ at $-33 \mathrm{kPa}$ and PWP at $-1500 \mathrm{kPa}$. In addition, clay content (\%) alone was used as an independent variable to relate FC and PWP. The relationship between clay content and hydraulic properties was evaluated, since the amount of clay in the soil sample is one of the easily measurable properties compared to the others. Similarly, PTFs were developed to predict infiltration rate for Karnataka from a database of 100 observations/soils.

Cross-validation was carried out to analyse the performance of PTF models. Ten-fold cross-validation techniques with 20 times repetition were used to evaluate the performance with indicators such as coefficient of determination $\left(R^{2}\right)$, root mean square error (RMSE) and mean error (ME). Coefficient of determination is defined by the percentage of variation explained by the model. Good models have coefficient of determination equal or close to 1 , and RMSE close to 0 .

$$
\text { Coefficient of determination }\left(R^{2}\right)=1-\frac{\sum_{i=1}^{n}\left(p_{i}-o_{i}\right)^{2}}{\sum_{i=1}^{n}\left(o_{i}-\bar{o}_{l}\right)^{2}} \text {, }
$$

$$
\begin{aligned}
& \operatorname{Bias}(\mathrm{ME})=\frac{1}{n} \sum_{i=1}^{n}\left(o_{i}-p_{i}\right), \\
& \operatorname{RMSE}=\sqrt{\frac{1}{n} \sum_{i=1}^{n}\left(o_{i}-p_{i}\right)^{2}},
\end{aligned}
$$

where $p_{i}$ and $o_{i}$ are the predicted and observed values, $\bar{o}_{l}$ is the mean of observed values.

Table 1 provides descriptive statistics of soil properties of NKP soils. $\mathrm{pH}$ of the soils ranges from very strongly acidic to very strongly alkaline, with a mean of 8.1. EC 


\section{RESEARCH COMMUNICATIONS}

Table 1. Statistics of physico-chemical soil properties in Northern Karnataka Plateau $(N=512)$

\begin{tabular}{|c|c|c|c|c|c|c|c|c|c|c|}
\hline Property & $\mathrm{pH}$ & $\mathrm{EC}(\mathrm{dS} / \mathrm{m})$ & $\mathrm{OC}(\%)$ & $\begin{array}{c}\text { Sand } \\
(\%)\end{array}$ & Clay (\%) & Silt (\%) & $\mathrm{FC}(\%)$ & PWP (\%) & $\begin{array}{c}\mathrm{CEC} \\
\left(\mathrm{C} \mathrm{mol} \mathrm{p}{ }^{+} \mathrm{kg}^{-1}\right)\end{array}$ & $\operatorname{ESP}(\%)$ \\
\hline Mean & 8.1 & 0.4 & 0.5 & 39.8 & 43.2 & 17.1 & 29.9 & 19.0 & 33.6 & 7.0 \\
\hline Maximum & 10.4 & 6.5 & 1.6 & 94.0 & 80.8 & 40.7 & 62.1 & 43.7 & 80.9 & 68.5 \\
\hline Minimum & 4.7 & 0.0 & 0.03 & 2.7 & 1.2 & 2.4 & 3.2 & 0.9 & 1.7 & 0.0 \\
\hline $\mathrm{SD}$ & 1.0 & 0.6 & 0.3 & 24.3 & 19.6 & 7.7 & 13.3 & 10.9 & 21.0 & 11.9 \\
\hline Kurtosis & 0.4 & 38.0 & 0.3 & -1.0 & -0.9 & -0.3 & -0.9 & -0.9 & -1.2 & 7.9 \\
\hline Skewness & -0.8 & 5.4 & 0.6 & 0.3 & -0.2 & 0.4 & 0.1 & 0.3 & 0.3 & 2.7 \\
\hline CV (\%) & 12.4 & 177.3 & 48.2 & 61.2 & 45.4 & 45.2 & 44.6 & 57.4 & 62.3 & 170.7 \\
\hline
\end{tabular}

EC, Electrical conductivity; OC, organic carbon; FC, field capacity; PWP, permanent wilting point; CEC, cation exchange capacity; ESP, exchangeable sodium percentage.

Table 2. Statistics of physico-chemical soil properties in Southern Karnataka Plateau $(N=228)$

\begin{tabular}{|c|c|c|c|c|c|c|c|c|c|c|}
\hline Property & $\mathrm{pH}$ & $\mathrm{EC}(\mathrm{dS} / \mathrm{m})$ & OC (\%) & $\begin{array}{l}\text { Sand } \\
(\%)\end{array}$ & Clay (\%) & Silt (\%) & $\mathrm{FC}(\%)$ & PWP (\%) & 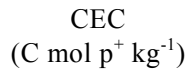 & $\operatorname{ESP}(\%)$ \\
\hline Mean & 7.6 & 0.10 & 0.40 & 53.5 & 31.5 & 15.0 & 22.2 & 11.4 & 14.7 & 3.0 \\
\hline Minimum & 4.5 & 0.02 & 0.08 & 4.4 & 5.8 & 2.0 & 4.1 & 2.1 & 52.6 & 33.1 \\
\hline Maximum & 9.1 & 0.48 & 2.00 & 92.3 & 67.8 & 36.0 & 70.9 & 41.0 & 1.2 & 0.0 \\
\hline SD & 0.9 & 0.08 & 0.23 & 16.5 & 13.1 & 6.4 & 9.5 & 6.3 & 9.5 & 3.4 \\
\hline Kurtosis & 0.1 & 2.98 & 10.49 & 0.7 & -0.2 & 0.7 & 5.4 & 3.1 & 2.9 & 28.3 \\
\hline Skewness & -0.8 & 1.57 & 2.22 & -0.6 & 0.3 & 1.0 & 1.8 & 1.5 & 1.6 & 4.2 \\
\hline CV (\%) & 12.0 & 81.7 & 57.81 & 30.9 & 41.5 & 42.8 & 43.1 & 55.4 & 65.1 & 115.1 \\
\hline
\end{tabular}
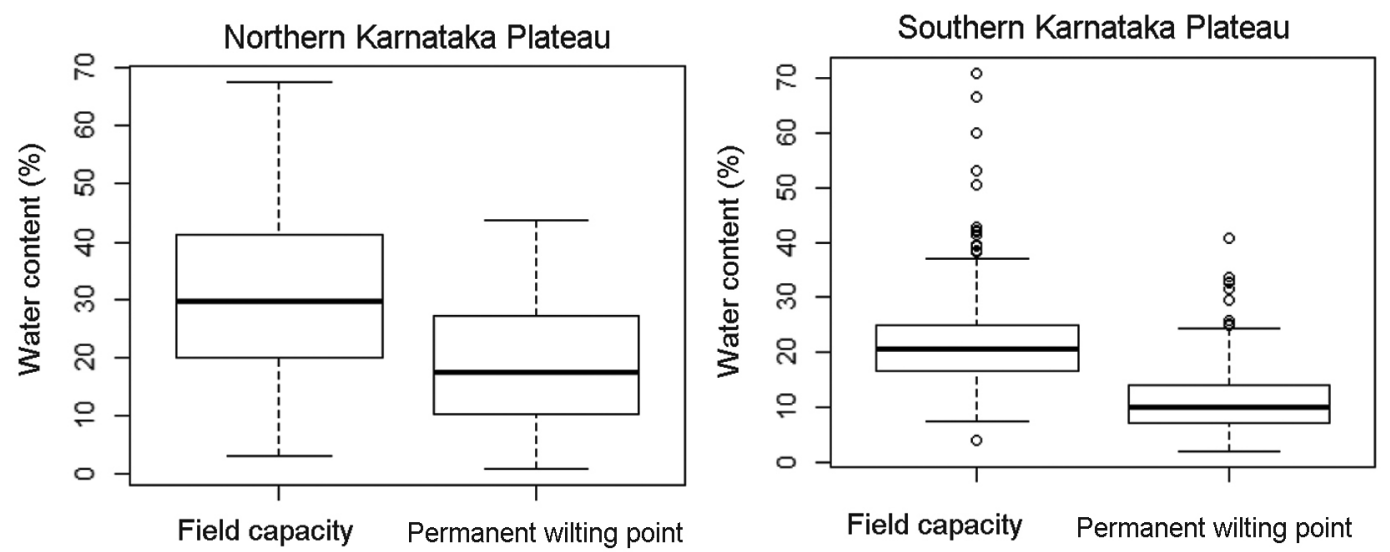

Figure 2. Distribution of field capacity and permanent wilting point in Northern Karnataka Plateau and Southern Karnataka Plateau.

of the soil also varies from 0.0 to $6.5 \mathrm{dSm}^{-1}$. OC ranges between $0.03 \%$ and $1.6 \%$, with mean of $0.5 \%$. The clay, sand and silt contents vary between $1.2 \%$ and $80.8 \%$, $2.7 \%$ and $94 \%$ and $2.4 \%$ and $40.7 \%$ respectively. CEC in NKP soils ranges from 1.7 to $80.9 \mathrm{C} \mathrm{mol} \mathrm{p}+\mathrm{kg}^{-1}$. The maximum exchangeable sodium percentage recorded in NKP soils is 68.5 . The FC and PWP range from $3.2 \%$ to $62.1 \%$ (mean $29.9 \%$ ) and $0.9 \%$ to $43.7 \%$ (mean $19.0 \%$ ) respectively, with high coefficient of variation (Figure 2). Except $\mathrm{pH}$ and clay, other parameters are positively skewed.

Table 2 provides descriptive statistics of soil properties of SKP soils. $\mathrm{pH}$ of the soils ranges from very strongly acidic (4.5) to very strongly alkaline (9.1), with a mean of
7.6. EC of the soil varies from 0.02 to $0.48 \mathrm{dS} \mathrm{m}^{-1}$. OC content ranges from $0.08 \%$ and $2.0 \%$, with a mean of $0.4 \%$. The clay, sand and silt contents vary between $5.8 \%$ and $67.8 \%, 4.4 \%$ and $92.3 \%$ and $2.0 \%$ and $36.0 \%$ respectively. The EC in SKP soils ranges from $4.1 \%$ to $70.9 \%$ with a mean of $22.2 \%$, while PWP ranges from and $2.1 \%$ to $41.0 \%$ with a mean of $11.4 \%$. CEC $\left(\mathrm{C} \mathrm{mol} \mathrm{p} \mathrm{kg}^{-1}\right)$ of the soil varies from 1.2 and 52.6 with mean value of 14.7 . Except $\mathrm{pH}$ and sand content, other parameters are positively skewed, and among the soil properties, soil $\mathrm{pH}$ shows least variability with $12 \% \mathrm{CV}$.

The results of correlation studies show that FC in NKP soils is significantly positively correlated with CEC $(0.867 * *)$, clay $\left(0.848^{* *}\right)$ and silt $(0.549 * *)$, and 

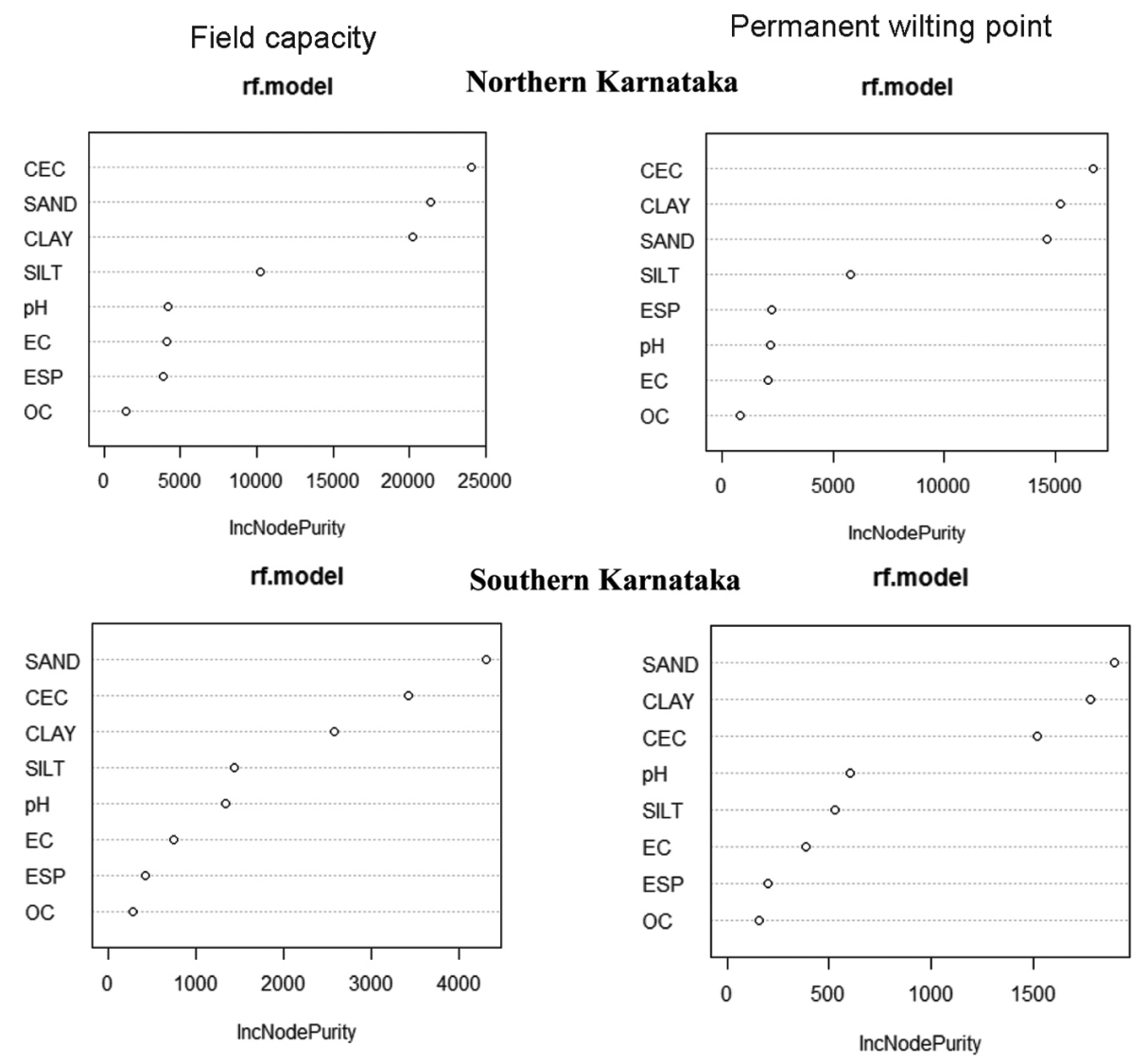

Figure 3. Variable importance rankings in predicting soil moisture constants in NKP and SKP.
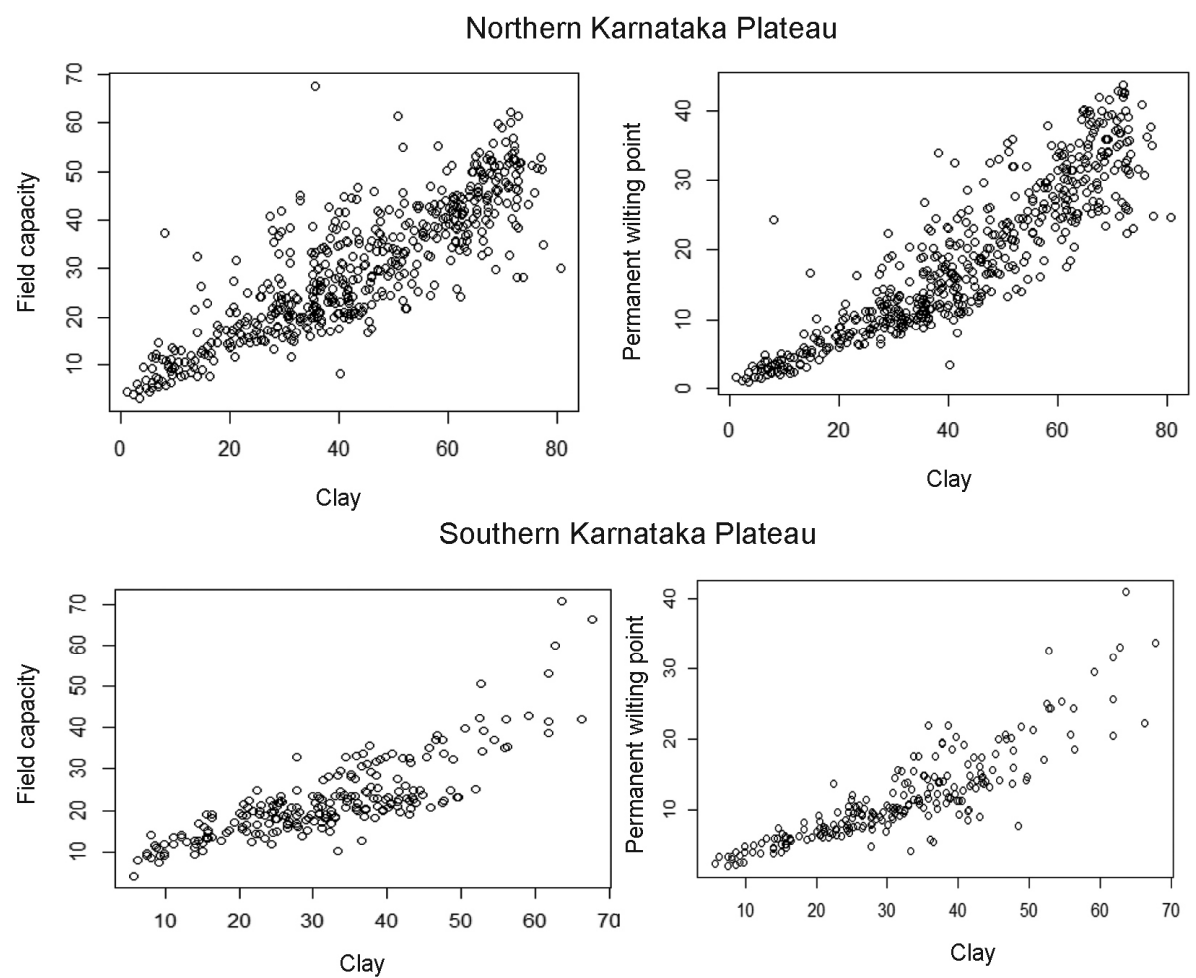

Figure 4. Relationship between soil moisture constants and clay content in NKP and SKP. 
Table 3. Multiple regression analysis of water content at field capacity and permanent wilting point in NKP

\begin{tabular}{lccccc}
\hline & \multicolumn{2}{c}{ Field capacity } & & \multicolumn{2}{c}{ Permanent wilting point } \\
\cline { 2 - 3 } \cline { 5 - 6 } Property & Estimate & Standard error & & Estimate & Standard error \\
\hline Intercept & 13.82 & $3.823^{* * * *}$ & & -5.776 & $2.724^{*}$ \\
Clay & 0.205 & $0.046^{* * *}$ & & 0.315 & $0.033^{* * *}$ \\
Sand & -0.088 & $0.042^{*}$ & & 0.050 & 0.030 \\
CEC & 0.316 & $0.025^{* * *}$ & & 0.271 & $0.018^{* * *}$ \\
\hline
\end{tabular}

$* * *$ Significant at $0.001 ; *$ Significant at 0.05 .

Table 4. Regression analysis of water content at field capacity and permanent wilting point using clay content in NKP

\begin{tabular}{lccccc}
\hline & \multicolumn{2}{c}{ Field capacity } & & \multicolumn{2}{c}{ Permanent wilting point } \\
\cline { 2 - 3 } \cline { 5 - 6 } Property & Estimate & Standard error & & Estimate & Standard error \\
\hline Intercept & 4.968 & $0.789^{* * *}$ & & -2.443 & $0.520^{* * *}$ \\
Clay & 0.586 & $0.017^{* * *}$ & & 0.500 & $0.011^{* * *}$ \\
\hline
\end{tabular}

$* * *$ Significant at 0.001 .

\section{Northern Karnataka Plateau}
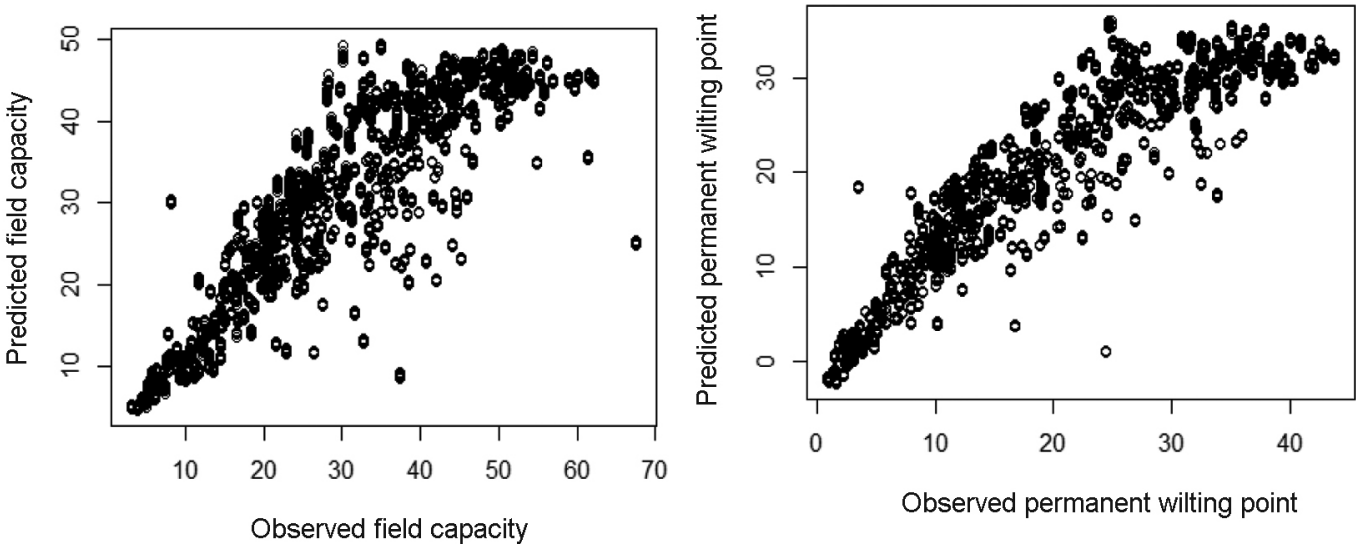

Observed permanent wilting point

Southern Karnataka Plateau
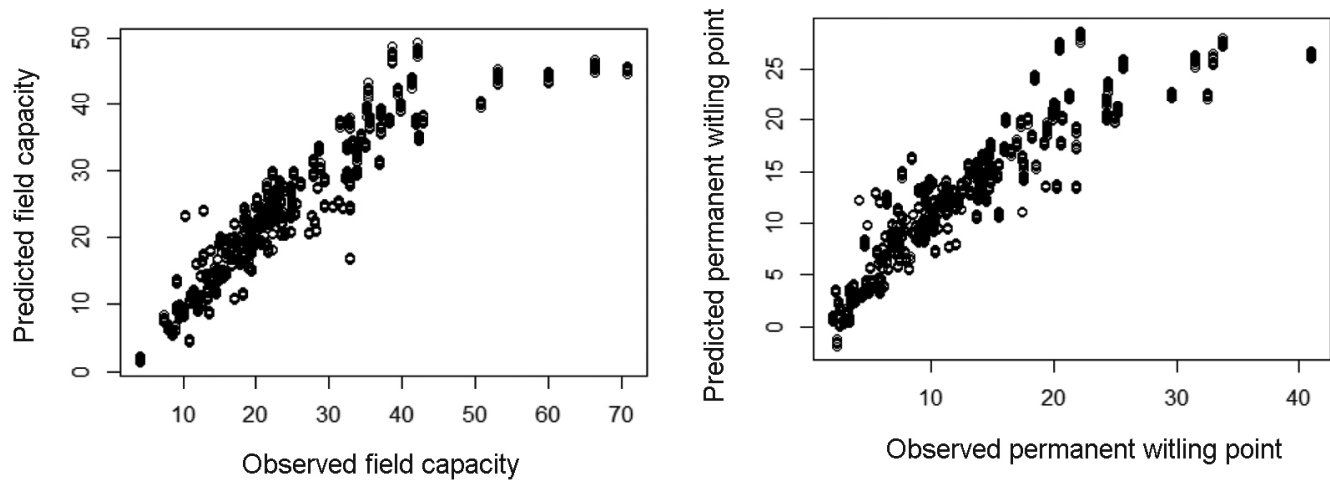

Observed permanent witling point

Figure 5. Observed and predicted soil moisture constants in NKP and SKP.

negatively correlated with sand $\left(-0.857^{* *}\right)$. PWP in NKP soils is significantly positively correlated with CEC $\left(0.902^{* *}\right)$, clay $\left(0.898^{* *}\right)$, silt $\left(0.526^{* *}\right)$, $\mathrm{pH}\left(0.335^{* *}\right)$, and negatively correlated with sand $(-0.890 * *)$. Like NKP soils, FC and PWP in SKP soils are significantly correlated with all the soil properties, except soil organic carbon. Adhikary et al. $^{26}$ also recorded that there is no significant relationship between soil organic matter and the corresponding FC and PWP in 800 samples studied across the country. 


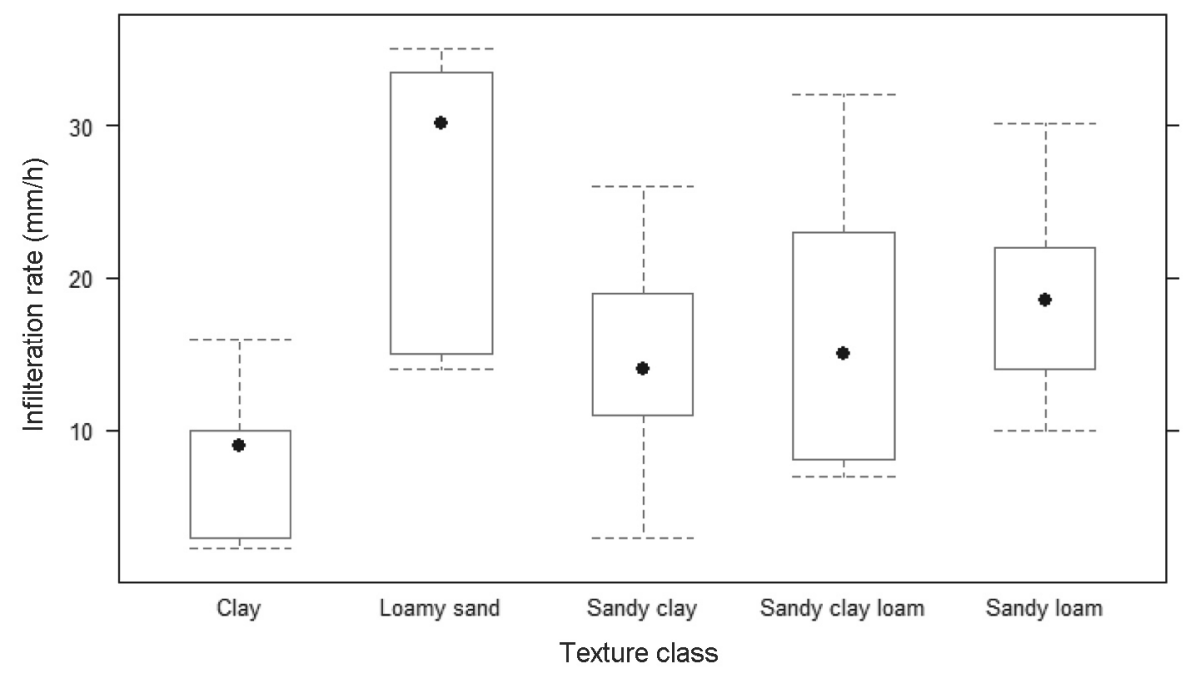

Figure 6. Infiltration rates under different texture classes in Karnataka.

Table 5. Multiple regression analysis of water content at field capacity and permanent wilting point in SKP

\begin{tabular}{lccccc}
\hline & \multicolumn{2}{c}{ Field capacity } & & \multicolumn{2}{c}{ Permanent wilting point } \\
\cline { 2 - 3 } \cline { 5 - 6 } Property & Estimate & Standard error & & Estimate & Standard error \\
\hline Intercept & 39.179 & $3.618^{* * *}$ & & 8.227 & $2.635^{* *}$ \\
Clay & -0.041 & 0.045 & & 0.168 & $0.032^{* * *}$ \\
Sand & -0.371 & $0.040^{* * *}$ & & -0.101 & $0.029^{* * *}$ \\
CEC & 0.257 & $0.035^{* * *}$ & & 0.217 & $0.025^{* * *}$ \\
\hline
\end{tabular}

***Significant at $0.001 ; *$ Significant at 0.01 .

Table 6. Performance of pedotransfer functions in predicting water content at field capacity (FC) and permanent wilting point (PWP)

\begin{tabular}{lrrrrr}
\hline & \multicolumn{2}{c}{ Northern Karnataka } & & \multicolumn{2}{c}{ Southern Karnataka } \\
\cline { 2 - 3 } \cline { 5 - 6 } Property & \multicolumn{1}{c}{ FC } & PWP & & \multicolumn{1}{c}{ FC } & \multicolumn{1}{c}{ PWP } \\
\hline$R^{2}(\%)$ & $83 \pm 5.4$ & $88 \pm 4.2$ & & $84 \pm 9.4$ & $83 \pm 8.6$ \\
Mean error & $-0.004 \pm 0.76$ & $-0.0002 \pm 0.54$ & & $-0.002 \pm 0.65$ & $0.001 \pm 0.5$ \\
RMSE & $5.25 \pm 0.80$ & $3.71 \pm 0.61$ & & $3.05 \pm 0.84$ & $2.17 \pm 0.53$ \\
\hline
\end{tabular}

The random forest model has the advantage that it helps to identify the importance of each predictor variable on prediction ${ }^{24,25}$. The analysis showed that CEC, sand and clay are the three top most important variables for prediction of FC and PWP in both regions (Figure 3 ). The order of important variables is $\mathrm{CEC}>$ sand $>$ clay for $\mathrm{FC}$, and $\mathrm{CEC}>$ clay $>$ sand for PWP in NKP soils. It is sand $>$ CEC $>$ clay for $\mathrm{FC}$, and sand $>$ clay $>$ CEC for PWP in case of SKP soils.

The PTFs were developed using the selected soil properties, viz. CEC, sand and clay as independent variables. The FC and PWP of soil were determined by the following equations

$$
\mathrm{FC}=a+b(\mathrm{CEC})+c(\text { sand })+d \text { (clay), }
$$

$$
\mathrm{PWP}=a+b(\mathrm{CEC})+c(\text { sand })+d \text { (clay), }
$$

where $a-d$ are the regression coefficients. The PTFs of soil hydraulic properties (FC and PWP) were developed separately for both regions, viz. North and South Karnataka. In case of infiltration rate, PTFs were developed for the entire Karnataka due to availability of limited datasets. The developed PTFs were cross-validated by ten-fold cross-validation techniques. Criteria of $1 \%$ and $5 \%$ level of significance were used for acceptance or rejection of a predictor variable in these models. The prediction of FC and PWP through the developed PTFs was satisfactory with low RMSE and high $R^{2}(64-88 \%)$, except PTF for infiltration rate which had poor and acceptable $R^{2}(41 \%)$.

For NKP, the PTFs of FC and PWP were developed using 512 soil layer observations of 100 profiles collected 
Table 7. Regression analysis of water content at field capacity and permanent wilting point using clay content in SKP

\begin{tabular}{lrrrrr}
\hline & \multicolumn{2}{c}{ Field capacity } & & \multicolumn{2}{c}{ Permanent wilting point } \\
\cline { 2 - 3 } \cline { 5 - 6 } Property & Estimate & Standard error & & Estimate & Standard error \\
\hline Intercept & 3.724 & $0.993^{* * *}$ & & -1.979 & $0.559^{* * * *}$ \\
Clay & 0.581 & $0.029^{* * *}$ & & 0.428 & $0.016^{* * *}$ \\
\hline
\end{tabular}

$* * *$ Significant at $0.001 ; * *$ Significant at 0.01 .

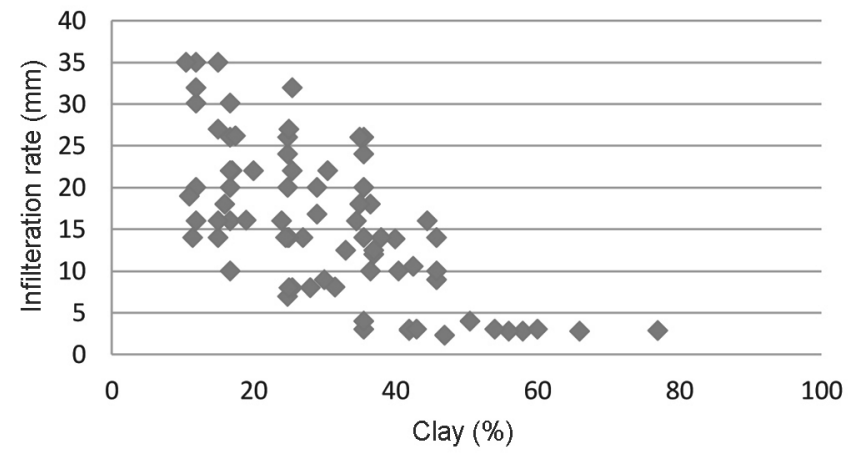

Figure 7. Infiltration rate versus clay content in Karnataka.

in Gulburga, Gadag, Yadgir and Koppal districts. Table 3 summarizes the results of PTFs developed for estimating water retention at FC and PWP in NKP soils. The equations are as follows

$\mathrm{FC}=13.82+0.205($ clay $)-0.088($ sand $)+0.316($ CEC $)$

$\mathrm{PWP}=-5.78+0.315$ (clay) $+0.050($ sand $)+0.271(\mathrm{CEC})$.

Clay with its large adsorption surface and CEC which reflects the negative charge of clay, greatly influence the soil water content due to adsorption of dipolar water molecules. The performance of PTF models in terms of $R^{2}$ value was higher for PWP $\left(R^{2}=88 \%\right)$ than for FC $\left(R^{2}=83 \%\right)$, which indicates that variables used in the PTF model explained $88 \%$ variation for PWP and $83 \%$ for FC. Sand negatively influences the prediction of FC, whereas it positively influences the prediction of PWP. Tiwary et al. ${ }^{18}$ developed PTFs for soil moisture content in basaltic region (black soil region), which is similar to NKP soils, using CEC, ESP and clay content of 75 soil layer observations of 14 soil profiles. The performance of PTFs were similar with $R^{2}$ of 0.82 and 0.71 for FC and PWP respectively. The errors of estimations, RMSE, were also found very low for both FC (5.2\%) and PWP (3.7\%) in NKP soils. Bias (mean error) of the estimated values of FC and PWP was found smaller for this regression model than other established PTFs in India ${ }^{1}$. Negative bias in the NKP soils indicates that predicted values are larger than observed values.

Among the soil properties, clay content can be easily measured or judged using different methods. When only clay content data are available, the following equation can be used to predict the FC and PWP in NKP soils (Figure 4, Table 4).

$$
\begin{aligned}
& \mathrm{FC}=4.97+0.586 \text { (clay), } \\
& \mathrm{PWP}=-2.44+0.50 \text { (clay). }
\end{aligned}
$$

The performance of regression model showed that $R^{2}$ value was higher for PWP (80\%) than FC (71\%). RMSE values for FC (7.05\%) and PWP (4.74\%) which were comparatively higher than PTFs developed using clay $+\mathrm{CEC}+$ sand models.

Table 5 summarizes the results of PTFs developed for estimating the water retention at FC and PWP for SKP soils. The equations are as follows

$\mathrm{FC}=39.18-0.041$ (clay) -0.371 (sand) $+0.257(\mathrm{CEC})$,

$\mathrm{PWP}=8.227+0.168($ clay $)-0.101($ sand $)+0.217(\mathrm{CEC})$.

Like NKP soils, the performance of PTF models (Table 5 ) in SKP soils in terms of $R^{2}$ value was higher for PWP $(88 \%)$ than FC $(84 \%)$, which indicates that variables explained more variation for PWP than FC. The relationship between predicted and observed soil moisture constants in NKP and SKP soils is depicted in Figure 5. Similar results were recorded by different researchers in India (Tiwary et al. ${ }^{18}, R^{2}=67-82 \%$; Mohanty et al. ${ }^{27}$, $R^{2}=85 \%$; Dabral and Pandey ${ }^{28}, R^{2}=80 \%$ ). In contrast to NKP soils, sand has negative influence on the prediction of both FC and PWP. RMSE values were also comparatively lower for both FC (3.05\%) and PWP (2.17\%) than NKP soils. Positive bias (mean error) was found for the prediction of PWP, whereas negative bias was observed for the prediction of FC (Tables 6 and 7).

The following equation can be used to predict soil moisture constants in SKP soils when only clay content data are available

$$
\begin{aligned}
& \mathrm{FC}=3.72+0.581 \text { (clay), } \\
& \mathrm{PWP}=-1.98+0.43 \text { (clay). }
\end{aligned}
$$

Like NKP soils, less performance was recorded for FCclay $\left(R^{2}=64 \%\right)$ and PWP-clay $\left(R^{2}=73 \%\right)$ models compared to FC/PWP-clay + CEC + sand model (Table 8 ). 


\section{RESEARCH COMMUNICATIONS}

Table 8. Performance of PTFs developed using clay content in predicting water content at field capacity and permanent wilting point

\begin{tabular}{lccccc}
\hline & \multicolumn{2}{c}{ Northern Karnataka } & & \multicolumn{2}{c}{ Southern Karnataka } \\
\cline { 2 - 3 } \cline { 5 - 6 } Property & FC & PWP & & FC & PWP \\
\hline$R^{2}(\%)$ & $71 \pm 8.2$ & $80 \pm 4.9$ & & $64 \pm 14$ & $73 \pm 10.7$ \\
Mean error & $0.001 \pm 1.0$ & $0.002 \pm 0.71$ & & $0.012 \pm 1.3$ & $0.006 \pm 0.7$ \\
RMSE & $7.05 \pm 1.01$ & $4.74 \pm 0.54$ & & $5.39 \pm 1.2$ & $3.13 \pm 0.68$ \\
\hline
\end{tabular}

Table 9. Multiple regression analysis of infiltration rate in Karnataka

\begin{tabular}{lcc}
\hline Property & Estimate & Standard error \\
\hline Intercept & 177.55 & $73.1^{*}$ \\
Clay & -1.80 & $0.75^{*}$ \\
Sand & -1.47 & $0.75^{*}$ \\
Silt & -1.58 & $0.69^{*}$ \\
\hline
\end{tabular}

* Significant at 0.05 .

Clayey soils retain more water than sandy soils. In both regions, i.e. NKP and SKP, higher $R^{2}$ was recorded for PWP than FC. Shwetha and Varija ${ }^{29}$ reported that water retention at lower tension (FC) does not mainly depend on soil texture like clay but on soil structure, but at higher tension (PWP) it depends on particle-size distribution and soil mineralogy.

Infiltration rate mainly depends on pore size and particle size. The PTFs for prediction of infiltration were developed from soil particles, viz. sand, silt and clay datasets of 100 observations in Karnataka (Figure 6 and Table 9). Infiltration rate varied from 2.3 to $35 \mathrm{~mm} / \mathrm{h}$, with mean and standard deviation of 15.69 and $8.75 \mathrm{~mm} / \mathrm{h}$ respectively. Infiltration rate $(\mathrm{mm} / \mathrm{h})$ increased with decreasing clay content (Figure 7, clay $(7.25)<$ sandy clay $(14.69)<$ sandy clay loam $(17.32)<$ sandy loam $(18.80)<$ loamy sand $(25.42))$. The regression model developed showed minimum RMSE (6.71\%) and acceptable $R^{2}$ value (41\%).

Infiltration rate $=177.55-1.47$ (sand)

$$
-1.80 \text { (clay) }-1.58 \text { (silt). }
$$

Adhikary et $a l .{ }^{26}$ found that infiltration rate has a power function relationship with clay content $\left(R^{2}=42 \%\right)$. The rate of decrease in infiltration rate is maximum till it reaches $20 \%$ clay, after which it reduces and becomes negligible. Mahdian et al. ${ }^{30}$ developed PTFs for infiltration rate using silt, clay, sand, BD, FC and PWP as input variables. The performance of PTFs was highly significant with $R^{2}$ of $74 \%$. Unlike soil moisture constants, only limited research has been carried out on soil infiltration rate which might be due to the complex process and high variance.

Characterizing soil response to hydrology is a challenging task, particularly because of the difficulty in quantifying soil hydraulic properties and their spatial variability. For practical applications of PTFs, we need approaches that provide for hydraulic information in a cost-effective manner, minimizing requirements for direct measurement of soil hydraulic properties. The PTFs developed in this study are improvized hydrologic predictions of semi-arid regions of southern India. Regular updation of PTFs with increased number of observations as well as increased number of independent variables like $\mathrm{BD}$ and aggregate stability will improve the results.

1. Santra, P., Mahesh Kumar, Kumawat, R. N., Painuli, D. K., Hati, K. M., Heuvelink, G. B. M. and Batjes, N. H., Pedotransfer functions to estimate water content at field capacity and permanent wilting point in hot arid western India. J. Earth Syst. Sci., 2018, 127, 35.

2. Simpson, J. A. and Weiner, E. S. C., The Oxford English Dictionary, Clarendon Press, Oxford University Press, Oxford, UK, 1989, 2nd edn

3. Ferré, T. P. A. and Warrick, A. W., Infiltration. In Encyclopedia of Soils in the Environment, 2005, pp. 254-260.

4. Romano, N. and Palladino, M., Prediction of soil water retention using soil physical data and terrain attributes, J Hydrol., 2002, 265, 56-75.

5. Parasuraman, K., Elshorbagy, A. and Bing, C. S., Estimating saturated hydraulic conductivity using genetic programming, Soil Sci. Soc. Am. J., 2007, 71, 1676-1684.

6. Vereecken, H., Weynants, M., Javaux, M., Pachepsky, Y., Schaap, M. G. and van Genuchten, M. Th., Using pedotransfer functions to estimate the van Genuchten-Mualem soil hydraulic properties: a review. Soil Sci. Soc. Am. J., 2010, 9, 795-820; doi:10.2136/ vzj2010.0045.

7. Dharumarajan, S., Singh, S. K., Bannerjee, T. and Sarkar, D., Water retention characteristics and available water capacity in three cropping system of lower Indo Gangetic alluvial plain. Commun. Soil Sci. Plant Anal., 2001, 4, 2734-2745.

8. Bouma, J., Using soil survey data for quantitative land evaluation, Adv. Soil Sci., 1989, 9, 177-213.

9. Rawls, W. J., Pachepsky, Y. A., Ritchie, J. C., Sobecki, T. M. and Bloodworth, H., Effect of soil organic carbon on soil water retention. Geoderma, 2003, 116, 61-76.

10. Tóth, B., Makó, A., Guadagnini, A. and Tóth, G., Water retention of salt affected soils: quantitative estimation using soil survey information. Arid Land Res. Manage., 2012, 26, 103-121.

11. Keshavarzi, A., Sarmadian, F. and Labbafi, R., Developing pedotransfer functions for estimating field capacity and permanent wilting point using fuzzy table look up scheme. Comput. Inf. Sci., 2011, 4(1), 130-141.

12. Santra, P. and Das, B. S., Pedotransfer functions for soil hydraulic properties developed from a hilly watershed of eastern India. Geoderma, 2008, 146, 439-448.

13. Chakraborty, D., Mazumdar, S. P., Garg, R. N., Banerjee, S., Santra, P., Singh, R. and Tomar, R. K., Pedotransfer functions for predicting points on the moisture retention curve of Indian soils. Indian J. Agric. Sci., 2011, 81, 1030-1036.

14. Patil, N. G. and Chaturvedi, A., Pedotransfer functions based on nearest neighbour and neural networks approach to estimate available water capacity of shrink-swell soils. Indian J. Agric. Sci., 2012, 82, 35-38. 
15. Cornelis, W. M., Ronsyn, J., van Meirvenne, M. and Hartmann, R., Evaluation of pedotransfer functions for predicting the soil moisture retention curve. Soil Sci. Soc. Am. J., 2001, 65, 638-648.

16. Kaur, R., Kumar, S., Gurung, R. P., Rawat, J. S., Singh, A. K., Prasad, S. and Rawat, G., Evaluation of pedotransfer functions for predicting field capacity and wilting point moisture content from routinely surveyed soil texture and organic carbon data. J. Indian Soc. Soil Sci., 2002, 50, 205-208.

17. Patil, N. et al., Soil water retention characteristics of black soils of India and pedotransfer functions using different approaches. J. Irrig. Drain Eng., 2013, 139, 313-324.

18. Tiwary, P. et al., Pedotransfer functions: a tool for estimating hydraulic properties of two major soil types of India. Curr. Sci., 2014, 107, 1431-1439.

19. NBSS Publication, Soils of Karnataka. In Soils of Karnataka for Optimizing Land Use, ICAR-NBSS\&LUP, Nagpur, Maharashtra, Publ. No. 47, 1998.

20. Hegde, R., Niranjana, K. V., Srinivas, S., Danorkar, B. A. and Singh. S. K., Site-specific land resource inventory for scientific planning of Sujala watersheds in Karnataka. Curr. Sci., 2018, 115(4), 645-652.

21. ASTM, D3385-03 Standard test method for infiltration rate of soils in field using double-ring infiltrometer. In Annual Book of ASTM Standards 04.08, American Society of Testing Materials, West Conshohocken, PA, USA, 2003

22. Liaw, A. and Wiener, M., Classification and regression by randomForest. $R$ News, 2002, 2, 18-21.

23. Breiman, L., Random forests, Machine Learn, 2001; doi:10.1023/ A:1010933404324.

24. Dharumarajan, S., Bishop, T. F. A., Hegde, R. and Singh, S. K. Desertification vulnerability index - an effective approach to assess desertification processes: a case study in Anantapur District, Andhra Pradesh, India. Land Degrad. Dev., 2018, 29 150-161; https://doi.org/10.1002/ldr.2850.

25. Dharumarajan, S. et al., Biophysical and socio-economic causes for increasing fallow lands in Tamil Nadu. Soil Use Manage., 2017, 33, 487-498.

26. Adhikary, P. P. et al., Pedotransfer functions for predicting the hydraulic properties of Indian soils. Aust. J. Soil Res., 2008, 46, 476-484.

27. Mohanty, M., Sinha, N. K., Painuli, D. K., Bandyopadhyay, K. K., Hati, K. M., Reddy, K. S. and Chaudhary, R. S., Pedotransfer functions for estimating water content at field capacity and wilting point of Indian soils using particle size distribution and bulk density. J. Agric. Phys., 2014, 14(1), 1-9.

28. Dabral, P. P. and Pandey, P. K., Models to estimate soil moisture retention limits and saturated hydraulic conductivity. J. Indian Water Resour. Soc., 2016, 36(1), 50-55.

29. Shwetha, P. and Varija, K., Soil water-retention prediction from pedotransfer functions for some Indian soils. Arch. Agron. Soil Sci., 2013, 59(11), 1529-1543.

30. Mahdian, M. H., Oskoee, R. S., Kamali, K., Angoshtari, H. and Kadkhodapoor, M. A., Developing pedotransfer functions to predict infiltration rate in flood spreading stations of Iran. Res. J. Environ. Sci., 2009, 3(6), 697-704.

ACKNOWLEDGEMENTS. We thank all the University partners of Sujala III project (UAS, Bengaluru, UAS, Dharwad; UAHS, Shimoga; UAS, Raichur and UHS, Bagalkot) for providing infiltration data for this study. We also thank Karnataka Watershed Development Department and World Bank for funding the project.

Received 17 October 2018; revised accepted 7 January 2019

doi: $10.18520 / \mathrm{cs} / \mathrm{v} 116 / \mathrm{i} 7 / 1237-1246$

\section{Impact of Pusa hydrogel application on yield and productivity of rainfed wheat in North West Himalayan region}

\author{
Trisha Roy*, Suresh Kumar, Lekh Chand, \\ D. M. Kadam, Bankey Bihari, S. S. Shrimali, \\ Rajesh Bishnoi, U. K. Maurya, Madan Singh, \\ M. Muruganandam, Lakhan Singh, \\ S. K. Sharma, Rakesh Kumar and Anil Mallik \\ ICAR-Indian Institute of Soil and Water Conservation, \\ Dehradun 248 195, India
}

Farmers in the North West Himalayan region generally practise rainfed agriculture and have very limited scope for irrigation. Water scarcity is a major constraint for crop production in these areas. This problem exacerbates further during the Rabi season where vagaries of winter rain result in complete crop failure. This study was conducted in the Raipur Block of Dehradun district in the farmer's field to study the impact of hydrogel on yield and productivity of wheat. Hydrogel is a hydrophilic polymer having high water holding capacity and can provide water to crops during moisture stress. Hydrogel was applied in the field in $R a b i$ wheat with two broad treatments, i.e. with hydrogel (WH) and without hydrogel (WHO). Each treatment was replicated ten times, i.e. ten demonstrations were laid out in the field conditions. Hydrogel was applied at the rate of $5 \mathrm{~kg} \mathrm{ha}^{-1}$ and observations related to various plant growth parameters and yield were recorded. The plant population in hydrogel plots increased by $22 \%$ compared to the non-hydrogel treated plots. The effective tillers, plant height, ear length and grains per ear significantly improved due to hydrogel application. The total yield as well as grain yield increased significantly after hydrogel amendment. The improved performance of wheat upon hydrogel application was evident in the field. This technology could be promising in terms of productivity improvement of rainfed crops and in combating the moisture stress in agriculture.

Keywords: Hydrogel, Northwest Himalayas, rainfed wheat, yield.

DESPITE the fast-paced development in agricultural sector, a majority of the arable area in our country (i.e. around $67 \%$ of the net sown area) still remains under rainfed condition ${ }^{1}$. Even after achievement of full irrigation potential of the country by various Government schemes like the 'Pradhan Mantri Krishi Sinchayi Yojna' and 'Har Khet Ko Pani' about $40 \%$ of the agricultural land is still in need of irrigation. Thus, a majority of the cultivated area across the length and breadth of the country is primarily dependent on the monsoon for livelihood

*For correspondence. (e-mail: trisha17.24@gmail.com) 